\title{
C-15 Halogenated Acetogenin with Antibacterial Activity against Food Pathogens
}

\section{Charles S. Vairappan* \& Tan Kai Lee}

Laboratory of Natural Product Chemistry, Institute for Tropical Biology and Conservation, Universiti Malaysia Sabah, 88999 Kota Kinabalu, Sabah. *csv@ums.edu.my (corresponding author )

Received on $22^{\text {nd }}$ June 2009, accepted in revised form $3^{\text {rd }}$ November 2009.

ABSTRACT As part of our continuous effort in search of bioactive secondary metabolites from marine organisms, we studied a specimen of red algae, Laurencia nangii Masuda from Banggi Island, Kudat District, Sabah. One C-15 acetogenin was isolated and identified as Z-dihydrorhodophytin (1,15\%). This compound showed $100 \%$ inhibition against the tested bacteria at $30 \mu \mathrm{gdisc}^{-1}$. MIC values for Salmonella enteritidis, Vibrio cholerae and Staphalococcus aereus were $1.25 \mu \mathrm{gdisc}^{-1}, 2.25 \mu \mathrm{gdisc}^{-1}$ and $2.25 \mu \mathrm{gdisc}^{-1}$, respectively; while Escherichia coli, Salmonella typhii and Salmonella thphymunium were inhibited at MIC value of $7.25 \mu \mathrm{gdisc}^{-1}$. This study showed that Z-dihydrorhodophytin (1) has significant antibacterial activity against the tested food pathogens and may have potential to be used as lead pharmaceutical drug candidate in combating "antibiotic resistant bacteria".

ABSTRAK Sehubungan dengan usaha kami untuk mengkaji sebatian sekunder bioaktif daripada organisma marin, kami telah menyelidik satu spesimen alga merah, Laurencia nangii Masuda dari Pulau Banggi, Kudat, Sabah. Satu sebatian C15-acetogenin telah dipencilkan dan dikenalpasti sebagai Z-dihydrorhodophytin (1, 15\%). Sebatian ini menunjukkan $100 \%$ perencatan pada $30 \mu \mathrm{gdisc}^{-1}$. Nilai MIC bagi Salmonella enteritidis, Vibrio cholerae dan Staphalococcus aereus adalah $1.25 \mu \mathrm{gdisc}^{-1}, 2.25 \mu \mathrm{gdisc}^{-1}$ dan $2.25 \mu \mathrm{gdisc}^{-1}$, manakala nilai untuk Escherichia coli, Salmonella typhii dan Salmonella thphymunium adalah $7.25 \mu \mathrm{gdisc}^{-1}$. Kajian ini menunjukkan bahawa Zdihydrorhodophytin (1) dapat merencatkan bakteria yang diuji dengan signifikan dan mempunyai potensi untuk dijadikan sebagai "lead drug" farmaseutikal dalam usaha mengawal "bakteria rintang antibiotik".

(Keywords: Laurencia nangii, C15-acetogenin, antibiotic resistant bacteria)

\section{INTRODUCTION}

Food-borne diseases are a growing concern in global public health services. It is estimated that as many as $30 \%$ of the population in industrialized countries suffer from food-borne illness annually. In 2005, 1.8 million people died of diarrhoeal disease and a great proportion of these cases can be attributed to contamination of food and drinking water [1]. The prevalent disease-causing microbes include Gramnegative bacteria such as Escherichia coli, Salmonella, Yersinia, Shigella, Aeromonas, Campylobacter and Vibrio, as well as Gram-positives bacteria such as Clostridium, Staphylococcus, Listeria, Bacillus, Streptococcus and Enterococcus [2]. Due to the rampant emergence of antimicrobialresistant strains like methicillin-resistant Staphylococcus aureus (MRSA) and vancomycinresistant Staphylococcus aureus (VRSA), there is an urgent need to discover new lead metabolites with potent antibacterial potential [3]. In light of these, there has been a consolidated effort among marine natural products chemists to explore new alternative drugs to combat and control food-borne diseases by incorporating approaches that reduces disease incidence and avoid negative side effects on human health [4]. In addition, there is also a growing awareness among consumers for increased safety, quality and shelf-life of foods with fewer synthetic additives [5]. This has made the exploration of antimicrobial agents from natural sources the only logical approach. The marine red algae genus Laurencia (Rhodomelaceae, Ceramiales) are well known source of halogenated secondary metabolites with potent antibacterial, antifungal, antiviral and antitumor properties $[6,7,8,9,10,11]$. In our continuous effort to search for bioactive metabolites from marine organisms $[12,13,14,15,16]$, we studied a specimen of red algae, Laurencia nangii Masuda from Banggi Island, Kudat District, Sabah. We wish to report herein the isolation, antibacterial activities and structure elucidation of $Z$ dihydrorhodophytin (1).

\section{MATERIALS AND METHODS}

\section{Collection}

Sample of Laurencia nangii was collected from 
Banggi Island, Kudat District, Sabah, Malaysia $\left(07^{\circ} 21.711^{\prime} \mathrm{N}, 117^{\circ} 15.223^{\prime} \mathrm{E}\right)$. Latitude and longitude were recorded using GPS 12XL (GARMIN Olathe, KS, USA). A voucher herbarium specimen, BORH 37588 (Figure 1) was deposited in Borneensis Herbarium Collection, Institute for Tropical Biology and Conservation, Universiti Malaysia Sabah.

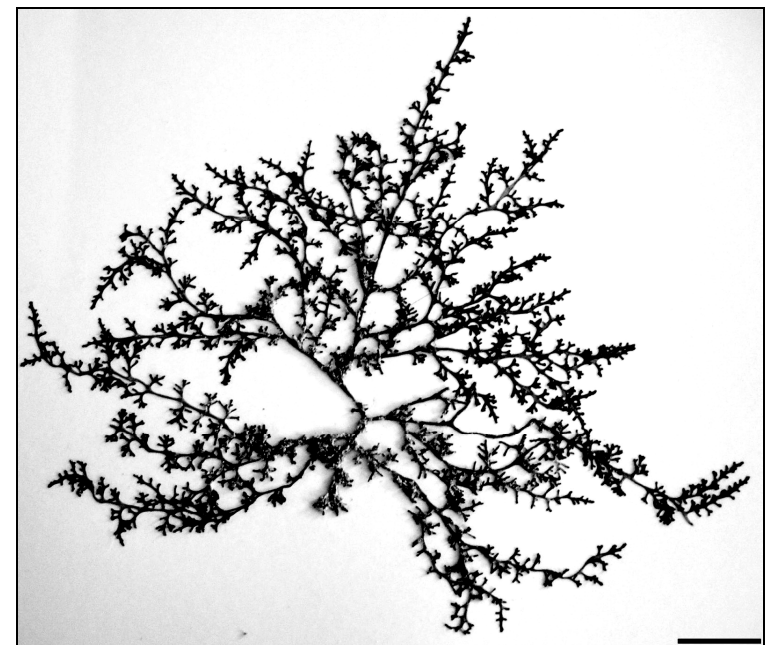

Figure 1. Herbarium specimen of Laurencia nangii Masuda (BORH 37588) collected from Banggi Island, Kudat District, Sabah. Scale bar $=1 \mathrm{~cm}$.

\section{Extraction and Isolation}

Partially dried sample (90 g) was soaked in methanol $(\mathrm{MeOH})$ for seven days. The $\mathrm{MeOH}$ solution was filtered and concentrated in vacuo and partitioned between diethyl ether $\left(\mathrm{Et}_{2} \mathrm{O}\right)$ and distilled water $\left(\mathrm{dH}_{2} \mathrm{O}\right)$ in the ratio of $1: 3(\mathrm{v} / \mathrm{v}) . \mathrm{Et}_{2} \mathrm{O}$ solution was washed with two changes of $\mathrm{dH}_{2} \mathrm{O}$, dried over sodium sulphate anhydrous $\left(\mathrm{Na}_{2} \mathrm{SO}_{4}\right)$ and evaporated in vacuo to obtain crude extract. Chemical profiling of the crude extract was done by spotting crude extract on $\mathrm{SiO}_{2}$ gel $\mathrm{F}_{254} \mathrm{~nm}$ Thin Layer Chromatography plates and developed in toluene (100\%) and Hexane: EtOAc (3:1) solvent systems. The spots on TLC were visualized by UV light ( 254 nm) and molybdophosphoric acid. High Performance Liquid Chromatography profile of crude extract was obtained on a Shimadzu HPLC using Preparative pump LC-6AD, UV Detector SPD-20A and oven CTO-20A under isocratic mode of acetonitrile (MeCN) $70 \%$ at a flow rate of $2 \mathrm{~mL} \mathrm{~min}^{-1}$ in a phenyl hexyl, $10 \mathrm{~mm}$ x $250 \mathrm{~mm}$ column (Luna Phenomenax), UV detection at $220 \mathrm{~nm}$. Further separation of the active metabolite involved fractionation via silica gel (Merck, Kieselgel 60, 0.063-0.2 mm mesh) column chromatography with a step gradient of hexane and ethyl acetate (EtOAc); gradient ratios: 9.5:0.5, 8.0:2.0, 7.0:3.0, 6.0:4.0 and 5.0:5.0. Fraction one was further purified using
HPLC under isocratic mode of MeCN $70 \%$ at a flow rate of $4 \mathrm{~mL} \mathrm{~min}^{-1}$ in a phenyl hexyl, $10 \mathrm{~mm} \times 250$ mm column (Luna Phenomenax), UV detection at $220 \mathrm{~nm}$ to give Z-dihydrorhodophytin (1). Yield of compound is based on the weight of crude extract.

\section{Spectroscopy Measurement \\ ${ }^{1} \mathrm{H}-\mathrm{NMR}(600 \mathrm{MHz})$ and ${ }^{13} \mathrm{C}-\mathrm{NMR}(150 \mathrm{MHz})$ spectra were obtained in deuterated chloroform with tetramethylsilane as internal standard (coupling constant, $J$ in Hz) on a JEOL ECA 600 spectrometer, IR spectrum was measured on a Thermo Nicolet Avatar FTIR spectrophotometer, LREIMS and HREIMS were recorded on a JEOL JMS-A500 spectrometer. Optical rotation was measured on a JASCO DIP-140 polarimeter, while melting point was measured on a micro-melting point apparatus (Fisher Scientific) and uncorrected. Compound 1 was identified by comparison of spectral data with those reported in the literature.}

\section{Antibacterial Assay}

Antibacterial bioassay was carried out by paper disc diffusion method using six strains of foodborne pathogenic bacteria obtained from clinical pathological laboratory in Queen Elizabeth Hospital, Kota Kinabalu, Sabah, Malaysia. These bacteria were: Escherichia coli (E.c) (NIHJ C-1), Salmonella typhii (S.ty) (NIHJ C-2), Salmonella enteritidis (S.e) (NIHJ C-3), Salmonella thphymunium (S.t) (SR08751), Vibrio cholerae (V.c) (SR0875-2) and Staphalococcus aereus (S.a) (SR0875-3). One loopful of bacteria was pre-cultured in nutrient broth (Oxoid, England) for 24 hours. The turbidity of culture was adjusted to optical density of McFarland $0.5[17,18]$. Then, $0.1 \mathrm{ml}$ of the precultured bacterial suspension was seeded on nutrient agar (Oxoid, England) plates. Paper discs (Whatman, $6 \mathrm{~mm}$ ) impregnated with $30 \mu \mathrm{g}$ disc $^{-1}$ of compound $\mathbf{1}$ were placed on the seeded agar plates. The diameters of inhibition zone were measured after 24 hours incubation at $28^{\circ} \mathrm{C}$. Potency of the compound was compared against four types of commercially available antibiotics (Biomérieux, France); Cefuroxime (CXM30), Tetracyclin (TE30), Minocycline (MI30) and Vancomycin (VA30). Concentration used was $30 \mu \mathrm{gdisc}^{-1}$, as recommended by the Clinical and Laboratory Standard Institute (CLSI). Minimum inhibition concentration (MIC) of compound 1 was determined using disc diffusion method as described above with the initial concentration of $10 \mu \operatorname{gdisc}^{-1}$, and reduced to $7.25 \mu \operatorname{gdisc}^{-1}, \quad 5.00 \mu \operatorname{gdisc}^{-1}, \quad 2.25 \mu \operatorname{gdisc}^{-1} \quad$ and $1.25 \mu \operatorname{gdisc}^{-1}$ by serial dilutions. 


\section{RESULTS}

Partially dried specimen of Laurencia nangii (90 g) was extracted in methanol and gave $1100 \mathrm{mg}$ of greenish paste-like crude extract. Figure 2 shows the retention time of the compound in its crude extract when analyzed via High Performance Liquid Chromatography (HPLC) under isocratic mode of $\mathrm{MeCN} 70 \%$ at flow rate of $2 \mathrm{~mL} \mathrm{~min}^{-1}$ via Phenyl Hexyl Luna column.

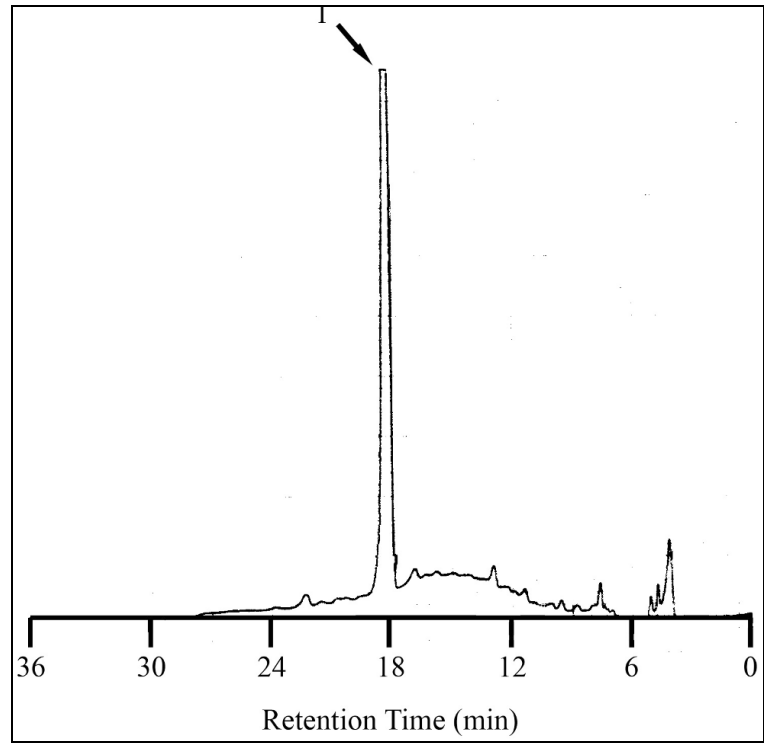

Figure 2. Relative retention time of Z-

dihydrorhodophytin (1) in crude methanol extracts of L. nangii (1: $18.1 \mathrm{~min})$.

The extract was then fractioned via $\mathrm{Si}$ gel column chromatography with step gradient of hexane and ethyl acetate. Fraction eluted with hexane: EtOAc (9.5:0.5) was further separated with reverse phase HPLC to yield compound $1(15.0 \%)$. The isolated pure compound was subjected to ${ }^{1} \mathrm{H}-\mathrm{NMR},{ }^{13} \mathrm{C}$ NMR, IR, LREIMS, HREIMS, optical rotation and melting point measurements. The $\mathrm{H}^{1}$-NMR data showed the presence of methyl protons at $\delta 1.08$, four sets of methylene protons at $\delta 1.91 / 2.00, \delta 2.25 / 2.55$, $\delta 2.58 / 2.73$ and $\delta 2.79 / 2.87$, four sets of methane protons at $\delta 4.02, \delta 4.05, \delta 4.11$ and $\delta 4.31$, one acetylenic proton at $\delta 3.14$. Presence of four olefinic protons was also detected at $\delta 5.55, \delta 5.77, \delta 5.85$, $\delta 6.06$. The presence of a 1-buten-3-ynyl moiety was evident from NMR spectra. The coupling constant value of $11.0 \mathrm{~Hz}$ for $\mathrm{H}-3$ and $\mathrm{H}-4$ as well as chemical shift value $(\delta 3.14)$ of the acetylenic proton indicated the geometry of the double bond at C-3 to be $Z$ configuration. Based on these information and HMBC data, the compound was determined as $Z$ dihydrorhodophytin (1) (Figure 3), previously reported from Laurencia pinnatifida [19]. Detailed spectroscopic data of Z-dihydrorhodophytin (1) is as shown below:

Z-dihydrorhodophytin (1)

Mp 36-38 ${ }^{\circ} \mathrm{C} ;[\alpha]_{\mathrm{D}}+69.45^{\circ}\left(c, 0.5, \mathrm{CHCl}_{3}\right)$; IR $(\mathrm{KBr})$ $v_{\max } \mathrm{cm}^{-1} 3280,3026,2924,2361,2336,1733,1436$, $1362,1321,1280,1248,1195,1162,1109,1072$, $800,763,710,659,624 ;{ }^{1} \mathrm{H}-\mathrm{NMR}\left(\mathrm{CDCl}_{3}, 600 \mathrm{MHz}\right)$ $\delta 1.08\left(3 \mathrm{H}, \mathrm{t}, J=7.6 \mathrm{~Hz} ; \mathrm{H}_{3}-15\right), 1.91(1 \mathrm{H}, \mathrm{dq}, J=15.2$, $7.6 \mathrm{~Hz} ; \mathrm{H}-14), 2.00(1 \mathrm{H}, \mathrm{m} ; \mathrm{H}-14), 2.25(1 \mathrm{H}, \mathrm{dd}$, $J=10.8,6.8 \mathrm{~Hz} ; \mathrm{H}-11), 2.56(1 \mathrm{H}, \mathrm{m} ; \mathrm{H}-11), 2.56(1 \mathrm{H}$, m; H-8), $2.73(1 \mathrm{H}$, ddd, J=14.5, 7.6, $6.9 \mathrm{~Hz} ; \mathrm{H}-8)$, 2.79 (1H, ddd, $J=14.4,8.3,5.5 \mathrm{~Hz} ; \mathrm{H}-5), 2.87(1 \mathrm{H}$, ddd, $J=14.4,6.9,5.5 \mathrm{~Hz}$; H-5), $3.14(1 \mathrm{H}, \mathrm{s} ; \mathrm{H}-1)$, $4.02(1 \mathrm{H}$, ddd, $J=14.7,4.8,4.1 \mathrm{~Hz} ; \mathrm{H}-13), 4.05(1 \mathrm{H}$, dd, $J=8.3,3.5 \mathrm{~Hz}$; H-7), $4.11(1 \mathrm{H}$, brd, $J=10.8 \mathrm{~Hz}$; H12), $4.31(1 \mathrm{H}$, ddd, $J=8.3,5.5,5.5 \mathrm{~Hz} ; \mathrm{H}-6), 5.55$ $(1 \mathrm{H}, \mathrm{d}, J=11.0 \mathrm{~Hz} ; \mathrm{H}-3), 5.77(1 \mathrm{H}, \mathrm{dd}, J=10.4,7.6$ $\mathrm{Hz}$; H-9), 5.85 (1H, ddd, $J=10.4,6.9,3.5 \mathrm{~Hz}$; H-10), $6.06(1 \mathrm{H}$, ddd, $J=11.0,8.3,6.9 \mathrm{~Hz} ; \mathrm{H}-4) ;{ }^{13} \mathrm{C}-\mathrm{NMR}$ $\left(\mathrm{CDCl}_{3}, 150 \mathrm{MHz}\right) \delta 141.8(\mathrm{C} 4), 130.7$ (C10), 127.9 (C9), 111.7 (C3), 83.2 (C1), 80.8 (C2), 79.7 (C12), 74.5 (C6), 64.9 (C7), 62.6 (C13), 35.9 (C5), 34.5 (C8), 32.1 (C11), 29.7 (C14), 13.2 (C15); LR-EIMS $\mathrm{m} / \mathrm{z}: \quad 330.0386 \quad(100.0 \%), \quad 332.0366 \quad(97.3 \%)$, 332.0357 (32.0\%), 334.0336 (31.1\%), 331.0420 $(16.2 \%), \quad 333.0399 \quad(15.8 \%), \quad 333.0390 \quad(5.2 \%)$, 335.0370 (5.0\%), 332.0453 (1.2\%), 334.0433 (1.2\%); HR-EIMS m/z: 331.6757. Calculated for $\mathrm{C}_{15} \mathrm{H}_{20}{ }^{79} \mathrm{Br}^{35} \mathrm{ClO} 330.0386$.

Antibacterial activity of Z-dihydrorhodophytin (1) was determined by testing it against food-borne human pathogenic bacteria obtained from clinical patients. Results of paper disc diffusion assay of the isolated compound were compared to the commercially available antibiotics as shown in Table 1. Z-dihydrorhodophytin (1) showed 100\% inhibition against the tested bacteria with comparable inhibitory zones to the commercially available antibiotics. The Minimum Inhibitory Concentration (MIC) of Zdihydrorhodophytin is shown in Figure 4. All the test bacteria were inhibited using a minimum concentration of $10 \mu \mathrm{gdisc}^{-1}$, further reduction in concentration gave selective inhibition as shown in Figure 3. Bacteria such as Salmonella enteritidis, Vibrio cholerae and Staphalococcus aereus were most sensitive with MIC values of $1.25 \mu \mathrm{gdisc}^{-1}, 2.25$ $\mu \operatorname{gdisc}^{-1}$ and $2.25 \mu \mathrm{gdisc}^{-1}$, respectively. The other three bacteria exhibited a MIC value of $7.25 \mu \mathrm{gdisc}^{-1}$. 

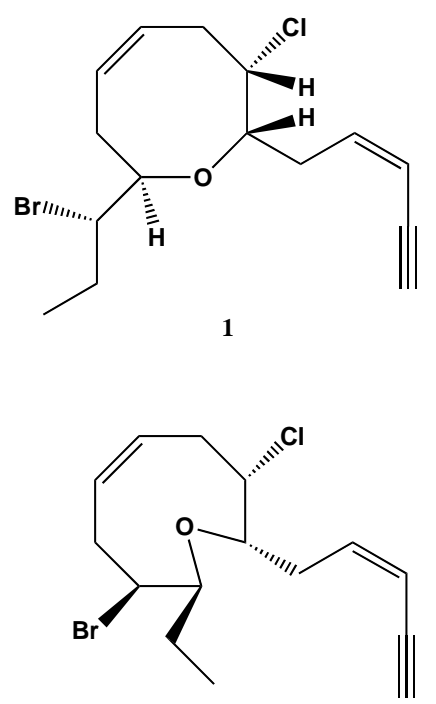

3

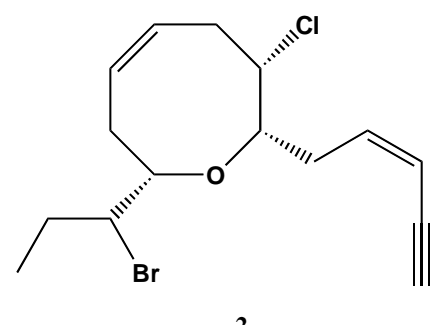

2

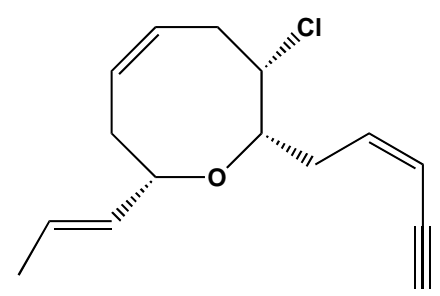

4

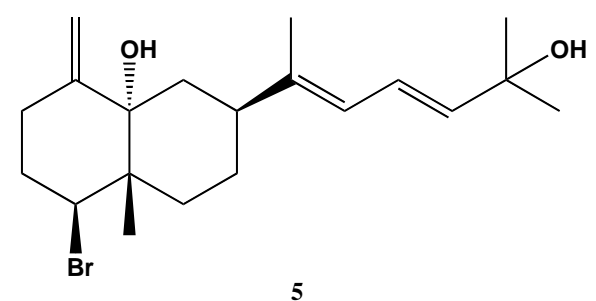

Figure 3. Chemical structures of Z-dihydrorhodophytin (1), cis-pinnatifidenyne (2), obtusenyne (3), 3Z-laurenyne (4) and aplysiadiol (5).

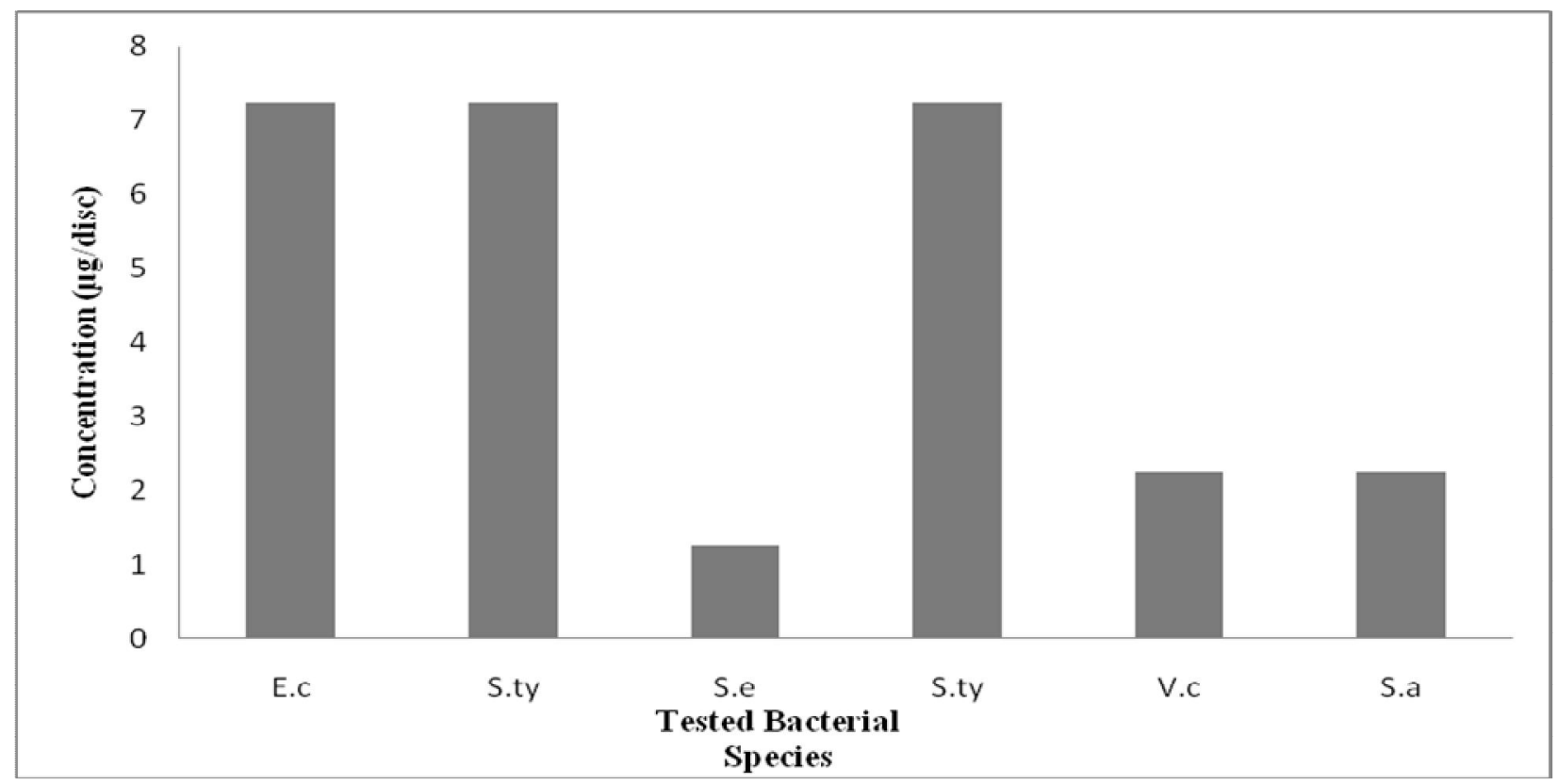

Figure 4. MIC values for Z-dihydrorhodophytin (1) against the tested bacteria. (E.c Escherichia coli (NIHJ C-1), S.ty Salmonella typhii (NIHJ C-2), S.e Salmonella enteritidis (NIHJ C-3), S.t Salmonella thphymunium (SR08751), V.c Vibrio cholerae (SR0875-2), S.a Staphalococcus aereus (SR0875-3)). 
Table 1. Comparative antibacterial activity of $Z$-dihydrorhodophyta (1) and four types of commercially available antibiotics against six strains of food-borne pathogenic bacteria. (CXM30 Cefuroxime, TE30 Tetracyclin, MI30 Minocycline, VA30 Vancomycin).

\begin{tabular}{lccccc}
\hline TEST BACTERIA & \multicolumn{5}{c}{ TEST COMPOUNDS } \\
\cline { 2 - 6 } & $(\mathbf{1})$ & CXM30 & TE30 & MI30 & VA30 \\
\cline { 2 - 6 } Escherichia coli (NIHJ C-1) & 18 & 7 & 25 & 28 & 32 \\
Salmonella typhii (NIHJ C-2) & 17 & 9 & 18 & 19 & 22 \\
Salmonella enteritidis (NIHJ C-3) & 11 & 8 & 20 & 21 & 19 \\
Salmonella thphymunium (SR0875-1) & 16 & 10 & 18 & 18 & 18 \\
Vibrio cholerae (SR0875-2) & 14 & 8 & 21 & 21 & 30 \\
Staphalococcus aereus (SR0875-3) & 12 & 10 & 19 & 17 & 28
\end{tabular}

Inhibition zone diameter: mm, -: no inhibition. Compound concentration: $30 \mu \mathrm{g}$ disc $^{-1}$ (CLSI levels)

\section{DISCUSSIONS}

Presence of halogenated secondary metabolites in red algae genus Laurencia is a well-documented fact, and its chemical diversity varies with species and geographical location where it thrives. However, there has only been one documented report on the presence of halogenated metabolites in L. nangii, its composition was identified as cis-pinnatifidenyne (2), obtusenyne (3), 3Z-laurenyne (4) and aplysiadiol (5) (Figure 3) [20]. However, the isolated metabolites were not tested for any biological potential. Hence, presence finding is an important discovery in terms of its chemical diversity as well as its biological activity. The isolated metabolite, Zdihydrorhodophytin (1), was present in a significantly high percentage as compared to the common amount of halogenated metabolites synthesized by any Laurencia species. Hence, making it possible to harvest a large amount of $Z$-dihydrorhodophytin (1) from this species.

More interestingly, upon screening against human pathogenic bacteria, it became apparent that Zdihydrorhodophytin has potent antibacterial potential. Detailed analysis of data presented in Table 1 revealed that Z-dihydrorhodophytin (1) showed better activity compared to cefuroxime. Commercial cefuroxime is a broad-spectrum third generation cephalosporin antibiotics with a typical $\beta$-lactam mode of action. Since, the tested microbes were obtained from clinical specimens, it is possible that they have acquired significant amount of resistant against conventional antibiotics with $\beta$-lactam mode of action. The other two antibiotics, tetracycline and minocycline are broad-spectrum polyketide antibiotics that inhibit protein synthesis by inhibiting the binding of aminoacyl-tRNA to the mRNAribosome complex. These two antibiotics showed significant inhibition against the proliferation of the tested food-borne pathogens. Antibacterial activity of $Z$-dihydrorhodophytin was not as good as vancomycin, hence, vancomycin maintained itself as the "last resort" drug against bacterial infection. Based on this study, it could be speculated that the test bacteria could have acquired slight resistant towards antibiotic having the $\beta$-lactam mode of action. Based on this investigation, it was apparent that Z-dihydrorhodophytin has better antibacterial potential than cefuroxime and no toxic activities against normal and tumor cell lines (Tan, 2009). Hence, it could be considered for topical application once the pharmacokinetics is done.

\section{CONCLUSIONS}

This study showed that Z-dihydrorhodophytin (1) inhibited the tested bacteria at notably low concentrations. Presence of strong antibacterial activity of Z-dihydrorhodophytin (1) promises new hope in our desperate attempt to discover potent drugs. Therefore, halogenated metabolites derived from marine red algal genus Laurencia may have some potential to be applied as effective drugs for controlling multi resistant bacteria. 


\section{ACKNOWLEDGEMENTS}

We are grateful to the Prof. Dr. Ridzwan and his team for the support and assistance during field survey. This study was funded under a research grant by the International Foundation for Science (IFS) and Committee for the Prohibition of Chemical Weapon, Hague, The Netherlands (IFS).

\section{REFERENCES}

1. World Health Organization (2007). Food Safety and Foodborne Illness. World Health Organization Fact sheet 237. Available from: www.who.int/mediacentre/factsheets/fs237/en. [Cited 3 March, 2009].

2. Heyndrickx, M., Rijpens, N. and Herman, L. (2001). Molecular detection and typing of foodborne bacterial pathogens: a review. In: Applied Microbiology - Focus on Biotechnology. (Eds. Durieux, A. and Simon, J. P.). Volume 2. Kluwer Academic Publishers, Boston, pp. 193238.

3. Sosa, A. (2006). The threat of antibiotic-resistance bacteria and the development of new antibiotics. In: Antimicrobial Resistance in Bacteria. (ed. Amábile-Cuevas, C. F.): Horizon Bioscience, UK, pp. 7-24.

4. Nedorostova, L., Kloucek, P., Kokoska, L., Stolcova, M. and Pulkrabek, J. (2009). Antimicrobial properties of selected essential oils in vapour phase against foodborne bacteria. Food Control 20: 157-160.

5. Bautista-Banos, S., Hernandez-Lauzardo, A. N., Velazquez-del Valle, M. G., Hernandez-Lopez, M., Barka, E. A. and Bosquez-Molina, E. (2006). Chitosan as a potential natural compound to control pre and postharvest diseases of horticultural commodities. Crop Protection 25: 108-118.

6. Caccamese, S., Azzolina, R., Duesler, E. N., Paul, I. C. and Rinehart, K. L. (1980). Laurencienyne, a new acetylenic cyclic ether from the marine red alga Laurencia obtusa. Tetrahedron Lett. 21: 2299-2302.

7. König, G. M. and Wright, A. D. (1997). Sesquiterpene content of antibacterial dichloromethane extract of the marine alga Laurencia obtusa. Planta Medica 63: 186-187.

8. Vairappan, C. S., Kawamoto, T., Miwa, H. and Suzuki, M. (2004). Potent antibacterial activity of halogenated compounds against antibioticresistant bacteria. Planta Medica 70: 1087-1089.

9. Sakemi, S., Higa, T., Jefford, C. W. and Bernardinelli, G. (1986). Venustatriol. A new, anti-viral, triterpene tetracyclic ether from
Laurencia venusta. Tetrahedron Lett. 27: 42874290.

10. Suzuki, T., Suzuki, M., Furusaki, A., Matsumoto, T., Kato, A., Imanaka, Y. and Kurosawa, E. (1985). Teurilene and thyrsiferyl 23-acetate, meso and remarkably cytotoxic compounds from the marine red alga Laurencia obtusa (Hudson) Lamouroux. Tetrahedron Lett. 26: 1329-1332.

11. Kladi, M., Xenaki, H., Vagias, C., Papazafiri, P. and Roussis, V. (2006). New cytotoxic sesquiterpenes from the red algae Laurencia obtusa and Laurencia microcladia. Tetrahedron 62: 182-189.

12. Vairappan, C. S., Daitoh, M., Suzuki, M., Abe, T. and Masuda, M. (2001). Antibacterial halogenated metabolites from the Malaysian Laurencia species. Phytochemistry 58: 291-297.

13. Vairappan, C. S. (2003). Potent antibacterial activity of halogenated metabolites from Malaysian red algae, Laurencia majuscula (Rhodomelaceae, Ceramiales). Biomol. Eng. 20: 255-259.

14. Vairappan, C. S., Ang, M. Y., Ong, C. Y. and Phang, S. M. (2004). Biologically active polybrominated indoles in the red alga Laurencia similis from the coastal waters of Sabah (Rhodomelaceae, Ceramiales). Malaysian J. Sci. 23: 119-126.

15. Vairappan, C. S. and Tan, K. L. (2005). Halogenated secondary metabolites from sea hare Aplysia dactylomela. Malaysian J. Sci. 24: 17-22.

16. Vairappan, C. S., Anangdan, S. P. and Tan, K. L. (2007). Additional halogenated secondary metabolites from the sea hare Aplysia dactylomela. Malaysian J. Sci. 26: 57-64.

17. Sonnenwirth, C. A., Jerett, L. (1980). Gradwohl's Clinical Laboratory Methods and Diagnosis, 8th ed. The C.V. Mosby Company, St. Louis, pp. 1959-1970.

18. Hindler, J. A., González, A. H. and Drake, T. A. (1990). Stability of viable-bacterium counts in liquid media used for preparation of inocula and subsequent impact on antimicrobial susceptibility test results. J. Clin. Microbiol. 28: 1271-1275.

19. Norte, M., Fernandez, J. J., Cataldo, F. and Gonzalez, A. G. (1989). E-dihydrorhodophytin, a $\mathrm{C}_{15}$ acetogenin from the red alga Laurencia pinnatifida. Phytochemistry 28: 647-649.

20. Masuda, M., Abe, T., Kogame, K., Kawaguchi, S., Phang, S. M., Daitoh, M., Sakai, T., Takahashi, Y. and Suzuki, M. (2002). Taxonomic notes on marine algae from Malaysia. VIII. Three species of Laurencia (Rhodophyceae). Bot. Mar. 45: 571-579. 